\title{
A Phonemic and Acoustic Analysis of Hindko Oral Stops
}

\author{
Haroon Ur RASHID \\ University of Azad Jammu and Kashmir, \\ Department of English \& Linguistics \\ kharoon914@gmail.com
}

\author{
Raja Nasim AKHTAR \\ University of Azad Jammu and Kashmir, \\ Department of English \& Linguistics \\ nasimakhtarraja@hotmail.com
}

\begin{abstract}
Hindko is an Indo-Aryan language that is mainly spoken in Khyber Pukhtoonkhaw province of Pakistan. This work aims to identify the oral stops of Hindko and determine the intrinsic acoustic cues for them. The phonemic analysis is done with the help of minimal pairs and phoneme distribution in contrastive environments which reveals that Hindko has twelve oral stops with three way series. The acoustic analysis of these segments shows that intrinsically voice onset time (VOT), closure duration and burst are reliable and distinguishing cues of stops in Hindko.
\end{abstract}

Keywords: Hindko oral stops; phonemic analysis; acoustic analysis; VOT; closure duration; burst

\section{Povzetek}

Hindko je indo-ajranski jezik, ki se večinoma govori v provinci Khyber Pukhtoonkhaw v Pakistanu. Namen raziskave je opredeliti ustne zapornike Hindka in določiti njihove akustične značilnosti. Fonemska analiza temelji na minimalnih parih in distribuciji fonemov $\mathrm{v}$ kontrastivnih okoljih. Iz rezultatov analize je razvidno, da ima Hindko dvanajst ustnih zapornikov v treh serijah. Akustična analiza teh segmentov je pokazala, da so v Hindku VOT, trajanje zapore in odpora zanesljivi in razločevalni ključi zapornikov.

Ključne besede: ustni zaporniki v Hindku; fonemska analiza; akustična analiza; VOT; trajanje zapore; odpora 


\section{Introduction}

Hindko belongs to the Indo-Aryan family of languages which has several dialects on a regional basis (Lothers \& Lothers, 2010). Hazara dialect is one of its main dialects that is spoken in Hazara division; Khyber Pukhtonkhawa province of Pakistan. The majority of Hindko speakers live in this area (Haroon \& Sohail, 2011).

Maddieson (1994) provides a survey of 562 languages which exhibits that the range of consonant inventories extends from a minimum of 6 consonants to a maximum of 122. Rotokas, spoken in Papua New Guinea, consists of only six consonants. While !Xoo, spoken in Botsowana has 122 consonants. Typically, consonant inventories size is in low twenties, i-e. $22( \pm 3)$. Such inventories have been categorized as average. The rest are categorized as small (from 6 to 14), moderately large (26-33), and large (34 or more consonants). Hindko has a moderately large consonant inventory.

Thirty consonants are identified in Hindko using minimal pairs as given below:

Table 1: Minimal Pairs of Consonants

\begin{tabular}{|c|c|c|c|c|}
\hline cons. & example & meaning & example & meaning \\
\hline$p$ & $\mathrm{pa}$ & 250 grams & $p^{h} a$ & gallows \\
\hline$p^{h}$ & $p^{h} \partial k k$ & swallow & pəkk & get coocked \\
\hline$b$ & bal & hairs & pal & brimg up \\
\hline t & tal & clean & $t^{\mathrm{h}} \mathrm{al}$ & big plate \\
\hline$t^{h}$ & $t^{\text {th}} \partial k \mathrm{k}$ & get tired & təkk & target \\
\hline d & d əll & grind & təll & roast \\
\hline$t$ & təkk & target & $t^{\mathrm{h}} \partial \mathrm{kk}$ & touch \\
\hline$t^{h}$ & $t^{\text {hok }}$ & wholesale & tok & interruption \\
\hline d & dill & compact piece of mud & till & power \\
\hline$k$ & kəmm & work & $k^{h} \partial m m$ & wing \\
\hline$k^{h}$ & $k^{h} v l l$ & open & kull & a type of prayer \\
\hline$g$ & gəll & talk & kəll & tomorrow \\
\hline $\mathrm{m}$ & məkk & maize & nəkk & nose \\
\hline$n$ & nũ & daughter in law & mũ & face \\
\hline$\eta$ & mən & beg & mənn & 40 kilo \\
\hline$f$ & farəkk & difference & varəkk & page \\
\hline v & vakztt & time & fak $\partial_{n \pi}$ & only \\
\hline
\end{tabular}




\begin{tabular}{|c|c|c|c|c|}
\hline cons. & example & meaning & example & meaning \\
\hline$s$ & soval & question & zoval & dusk \\
\hline$z$ & zəd d & reach & səd d & call \\
\hline $\int$ & Səll & freeze & səll & make hole \\
\hline$x$ & xəmm & curve & rəmm & sorrow \\
\hline$\gamma$ & ralaf & cover & xalaf & against \\
\hline$h$ & haləttt & condition & ralott & wrong \\
\hline $\mathrm{t} \int$ & $\mathrm{t} \int \partial \mathrm{mm}$ & skin & $\mathrm{t} \int^{\mathrm{h}} \partial \mathrm{mm}$ & make thin \\
\hline$t \int^{h}$ & $\mathrm{t} \int^{\mathrm{h}} a \mathrm{l}$ & jump & $\mathrm{t} \int a \mathrm{l}$ & move \\
\hline$d_{3}$ & dzutt & get busy & $\mathrm{t} \int u t t$ & lazy \\
\hline 1 & lətt & $\operatorname{leg}$ & ratt & blood \\
\hline$r$ & ror & roll & ror & small stone \\
\hline$r$ & bar & enter & bar & turn \\
\hline j & jəkk & idiot & fəkk & doubt \\
\hline
\end{tabular}

The table given below shows the summary of Hindko consonants.

Table 2: Hindko Consonant Phonemes

\begin{tabular}{|c|c|c|c|c|c|c|c|c|}
\hline & Bilabial & Labiod. & Dental & Alveolar & Retroflex & Palatal & Velar & Glottal \\
\hline Stops & $\begin{array}{cc}p & b \\
p^{h} & \end{array}$ & & $\begin{array}{ll}\mathrm{t}_{m} & \mathrm{~d} \\
\mathrm{t}_{n} & \end{array}$ & $\begin{array}{cc}t & d \\
t^{h} & \end{array}$ & & & $\begin{array}{cc}k & g \\
k^{h} & \end{array}$ & \\
\hline Nasals & $\mathrm{m}$ & & & $n$ & & & $\eta$ & \\
\hline Fricatives & & f $\quad v$ & & S $\quad z$ & & $\int$ & $x \quad \gamma$ & ศ \\
\hline Affricates & & & & & & $t \int^{\mathrm{h}} \mathrm{d}$ & & \\
\hline Lateral & & & & I & & & & \\
\hline Trill & & & & $r$ & & & & \\
\hline Flap & & & & & $r$ & & & \\
\hline Glides & & & & & & j & & \\
\hline
\end{tabular}

In order to establish oral stops of Hindko, the phonemic analysis, besides the minimal pairs given above in Table 1, includes voicing and aspiration contrast and word-level distribution of phonemes in initial, medial and end position. The next 
section describes the acoustic cues for plosives. It begins with the relevant literature on acoustic cues with a purpose to provide a foundation for the study. Then, the methodology is stated. In addition, this section also reflects the results of the study and states the intrinsic acoustic cues of Hindko stops. Mainly, the focus is on VOT, closure duration and burst.

\section{Phonemic analysis}

The phonemic analysis of Hindko oral stops is presented on the bases of voicing and aspiration distribution contrasts and word level distribution at initial, medial and end positions. This section offers the outcome of the analysis.

\subsection{Phonemes Distribution}

Following tables offer illustrations for stops in Hindko on the basis of voicing and aspiration contrasts. Table 5 exhibits equal distribution-word initial, medial and final positions.

Table 3: Voicing Contrast

\begin{tabular}{|c|c|c|c|c|}
\hline contrast & example & meaning & example & meaning \\
\hline \multirow{3}{*}{$p$ vs. b } & par & other side & bətt & knitt \\
\hline & $k^{h}$ әрра & gap & $k^{h} \partial b b a$ & lefty \\
\hline & nap & measure & $t \int o b$ & pain \\
\hline \multirow{3}{*}{ t vs. d } & tar & make swim & dar & flow \\
\hline & katã & big scissors & lado & grass on a tree \\
\hline & mat & defeat & kamad & a kind of rice \\
\hline \multirow{3}{*}{ t vs. d } & təkk & patch & dvll & fall \\
\hline & bata & strong & dada & dominating \\
\hline & dat & charm & $k^{h} v d d$ & corner \\
\hline \multirow{3}{*}{ k vs. g } & kal & scarcity & gal & melt \\
\hline & kaka & uncle & $\operatorname{degt} \int \mathrm{i}$ & small pot \\
\hline & tak & locate & $p^{h} a g$ & fig \\
\hline
\end{tabular}


Table 4: Aspiration Contrast

\begin{tabular}{|c|c|c|c|c|}
\hline contrast & example & meaning & example & meaning \\
\hline \multirow{3}{*}{$p$ vs. $p^{h}$} & pod & generation & $p^{h}$ er & turn \\
\hline & $\mathrm{t} \int ә р \mathrm{pa}$ & one fourth of bread & dzə弓 $p^{h} p^{h} a$ & embrace \\
\hline & NA & - & NA & - \\
\hline \multirow{3}{*}{${ }_{\pi}$ vs. $t_{n}^{\mathrm{h}}$} & tәpp & become furious & $t^{h} \partial p$ & paste \\
\hline & $g v_{n}^{n} t_{n}^{h} a$ & bag & bətr ${ }_{n}^{h} t^{h} \partial l$ & end part of a field \\
\hline & sat & seven & $n \partial_{n} t_{n}^{h} t^{h}$ & entangle \\
\hline \multirow{3}{*}{ t vs. $t^{h}$} & təkk & patch & $t^{\mathrm{h}} \partial \mathrm{kk}$ & pure \\
\hline & gita & small stone & $\operatorname{git}^{h} t^{h} a$ & small \\
\hline & mitt & reconcile & gIt $^{h} t^{h}$ & six inche \\
\hline \multirow{3}{*}{ k vs. $k^{h}$} & kətrot & lamb & $k^{h}$ ərra & upright \\
\hline & bəksi & small box & bək ${ }^{h} k^{h} i$ & side \\
\hline & əkk & irritated & buk $k^{h} k^{h}$ & hunger \\
\hline
\end{tabular}

Table 5: Word level distribution of stop phonemes

\begin{tabular}{|c|c|c|c|c|c|c|}
\hline & Initial & & Medial & & Final & \\
\hline$p$ & par & other side & tapo & $\begin{array}{l}\text { name of a box } \\
\text { in a game }\end{array}$ & $t \int ә p p$ & closed shut \\
\hline$p^{h}$ & $p^{h}$ ənd & an animal & $p^{h} u p^{h}$ era & cousin & NA & - \\
\hline$b$ & boti & bride & abla & pimple & $t \int \partial b b$ & chew \\
\hline $\mathrm{t}$ & taribri & cucunber & $p^{h}$ Itni & a wild plant & bat & a dish \\
\hline$t^{h}$ & $t^{\mathrm{h}} æ l i$ & bag & bit ${ }_{n}^{h} t^{h} \partial l$ & nursury & $\mathrm{bIt}_{n} \mathrm{t}^{\mathrm{h}} \mathrm{t}^{\mathrm{h}}$ & groove \\
\hline $\mathrm{d}$ & dõa & ox & dz əndra & lock & mãd & $\operatorname{dim}$ \\
\hline $\mathrm{t}$ & taki & mop & bati & strong & darat & sickle \\
\hline$t^{h}$ & $t^{\text {hok }}$ & set & $\mathrm{dIt}^{\mathrm{h}} \mathrm{t}^{\mathrm{h}} a$ & saw & $g \partial t^{h} t^{h}$ & knot \\
\hline d & dəll & stove side & udari & flight & vdd & fly \\
\hline$k$ & kvtt & beat & bəksa & box & bəkk & say (negative) \\
\hline$k^{h}$ & $k^{h}$ or & walnut & $k^{h} o^{h} a$ & shop & $r^{2} k^{h} k^{h}$ & grass field \\
\hline$g$ & ga & problem & $\operatorname{dog} a$ & field & $\mathrm{kag}$ & crow \\
\hline
\end{tabular}




\subsection{Discussion}

This analysis indicates that Hindko has twelve oral stops produced from four different places of articulation: bilabial $/ \mathrm{p}, \mathrm{b}, \mathrm{p}^{\mathrm{h}} /$, dental $/ \mathrm{t}, \mathrm{d}_{\mathrm{t}} \mathrm{t}^{\mathrm{h}} /$, alveolar $/ \mathrm{t}, \mathrm{d}, \mathrm{t}^{\mathrm{h}} /$ and velar $/ \mathrm{k}, \mathrm{g}, \mathrm{k}^{\mathrm{h}} /$. It also reflects that the oral stops display a three way voicing contrast. This is voiced $/ \mathrm{b}, \mathrm{d}, \mathrm{d}, \mathrm{g} /$, voiceless unaspirated $/ \mathrm{p}, \mathrm{t}, \mathrm{t}, \mathrm{k} /$ and voiceless aspirated $/ \mathrm{p}^{\mathrm{h}}, \mathrm{t}_{\mathrm{n}}^{\mathrm{h}}, \mathrm{t}^{\mathrm{h}}, \mathrm{k}^{\mathrm{h}} /$. All the voiceless phonemes have aspiration contrast but voiced aspirated stops are non-existent in Hindko. However, Kiyani et al (2012) claim that Hindko spoken in Neelum Valley being different from its dialects spoken in Kashmir and Pakistan has this contrast. Generally, voiced aspirated plosives are found in Indo-Aryan languages. Hussain (1997) reports that voiced stops are found in Urdu which is the second language of Hindko speakers. The analysis of Hazara Hindko given above does not support this finding. This analysis also demonstrates that Hindko plosives exist word initial, medial and final positions except $/ \mathrm{p}^{\mathrm{h}} /$ that is restricted to only word initially and medially. The following section presents an acoustic analysis of these segments.

\section{Acoustic analysis of Hindko stops}

Stops are articulated by complete closure of air in the vocal tract and then a sudden release of the blocked air at different places of articulation (Davenport and Hannahs, 2005). These have been studied widely in other languages.

\subsection{Acoustic Studies of Stops}

Phonetically groups of consonants differ from each other in a variety of acoustic parameters intrinsically and extrinsically. Kent and Read (1996) assert that consonants groups differ considerably in their acoustic cues; due to this are difficult to describe with a single set of acoustic properties. Some consonants are articulated with complete air blockage while other are produced with partial blockage. Some differ in release. Such differences constitute different groups of consonants, i-e. stops, fricatives, affricates, etc. All these have different distinguishing acoustic properties.

The literature on acoustic phonetics indicates that there are intrinsic as well as extrinsic cues to distinguish among stops. Kent and Read (1996) assert that voice onset time (henceforth VOT), closure and burst are intrinsic while neighboring vowel transition is an extrinsic cue of stops. As shown above, Hindko has three way contrasts in 12 oral stops namely voiced, voiceless aspirated and voiceless unaspirated. Maddieson's (1984) survey of 317 languages demonstrates that $25 \%$ of languages are with three stop series contrast. Hindko also has the same three way contrast of plosive segments. Ladefoged (2001) supplements the view that stops differ various ways on acoustic dimensions like VOT, the spectral characteristics of their release burst and formant transitions of surrounding vowels. This section aims to determine the acoustic cues of stops in Hindko which are produced from four different places as given below: 
Table 6: Stops of Hindko

\begin{tabular}{||l|c|c|c|c||}
\hline & Bilabial & Dental & Alveolar & Velar \\
\hline \hline Voiceless unaspirated & $\mathrm{p}$ & $\mathrm{t}$ & $\mathrm{t}$ & $\mathrm{k}$ \\
\hline Voiceless aspirated & $\mathrm{p}^{\mathrm{h}}$ & $\mathrm{t}^{\mathrm{h}}$ & $\mathrm{t}^{\mathrm{h}}$ & $\mathrm{k}^{\mathrm{h}}$ \\
\hline Voiced unaspirated & $\mathrm{b}$ & $\mathrm{d}$ & $\mathrm{d}$ & $\mathrm{g}$ \\
\hline
\end{tabular}

\subsection{VOT}

VOT is the interval between the release of a plosive and the onset of the vocal cords vibration and is measured from acoustic displays as the time between the release burst and the first quasi perdiosity in the acoustic signal (Lisker and Abramson 1964; Keating 1984; Klatt 1975). Three different types of VOT can be found. The first type is zero VOT in which the onset of vocal folds vibration approximately coincides with the stop release. The second one is positive VOT where there is a delay in the onset of vocal folds vibration after the stop release (also called lag VOT). This type is further divided into two namely short lag and long lag VOT. The third type is negative VOT, also known as lead VOT, in which the onset of vocal cords vibration precedes the plosive release. The following figure 1 demonstrates positive and negative VOT for Hindko velar stops $/ \mathrm{k} /$ and $/ \mathrm{g} /$ respectively.

This figure shows that /k/ has positive VOT as the circled area indicates while /g/ has negative VOT because the pitch contour preceding the release burst is clearly visible.

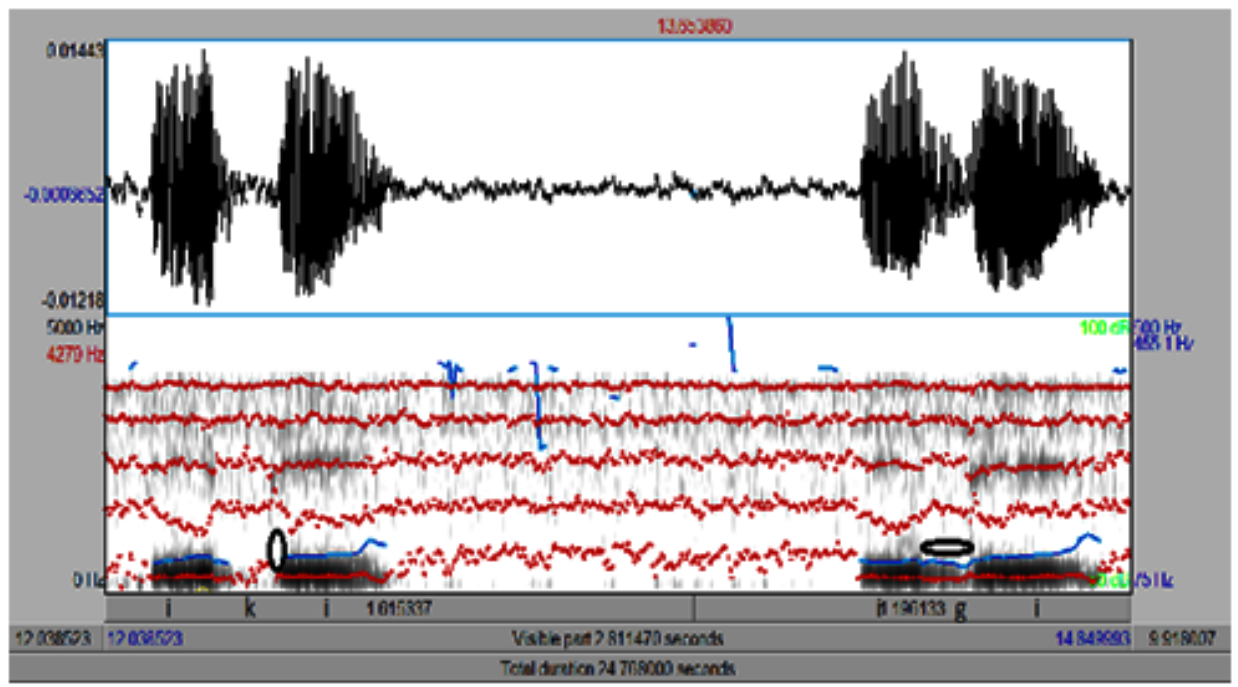

Figure 1: Spectrogram showing VOT for $/ \mathrm{k} /$ and $/ \mathrm{g} /$

There are various studies on VOT in different languages of the world indicating a variety of trends. These cross linguistic investigations show that there are three 
principal findings with respect to place of articulation of plosive: Firstly, the further back the closure, the longer the VOT (Fischer-Jorgensen, 1954; Peterson \& Lehiste, 1960). Secondly, the more extended the contact area, the longer the VOT (Stevens, Keyser \& Kawasaki, 1986). Finally, the faster the movement of the articulators is, the shorter the VOT (Hardcastle, 1973). Lisker and Abramson (1964) consider VOT as a strong cue to voicing contrast between plosives.

\subsection{Closure duration}

The closure duration of plosives is known as the acoustic interval corresponding to the articulatory occlusion (Kent \& Read, 1996). Maddieson (1991) states that the closure duration of a stop decreases with the backness of the tongue. Anderson \& Maddieson (1994) find in their study of Tiwi coronal stops that the closure duration of alveolar stops is the shortest one of all coronal segments.

\subsection{Burst as acoustic cue}

Usually, the spectrum of a stop burst varies with the place of articulation. Kent and Read (1996) associate the spectral variation to the fact that the short noise burst is shaped by the resonance attributes defined by particular articulatory configuration. The plosive burst is represented as a short vertical noise pulse with a specific center frequency. Halle, Hughes and Radley (1957) state that bilabial stops /p, b/ have low frequency concentration from $500-1500 \mathrm{~Hz}$ while alveolar /t, d/ had a high frequency above $4000 \mathrm{~Hz}$ whereas the velar $/ \mathrm{k}, \mathrm{g} / \mathrm{had}$ a strong concentration in the mid region of about 1500-4000 Hz. Stevens and Blumstein (1978) associate the spectral template with each place of articulation as bilabial a flat or falling spectrum; alveolar with a rising spectrum and velar with a compact (mid-frequency) spectrum.

Following section first states the methodology for acoustic analysis and then discusses the acoustic properties of Stops in Hindko.

\section{Methodology}

The methodology includes a description of participants, stimuli and procedure used to study Hindko plosives acoustically.

\subsection{Participants}

In total, ten Hindko speakers (five male and five female) participated in the study. The participants were born in Hazara Hindko dialectal area. All these are either in their twenties or thirties. Eight of them are graduate students while two are teachers at the university of AJ\&K. All the participants are multilingual. At home, they speak Hindko while elsewhere Urdu. However, classroom communication is in English to a great 
extent. None of them reported any history of language impairment. All of them had received no phonetic training and knowledge of this kind of experiment.

\subsection{Stimuli}

The stimuli contain Hindko words and non-words with a vowel-consonant-vowel (VCV) context, where $\mathrm{C}$ is the target stop consonant. To minimize variation from the vowel context, the same vowel /i/ is used both in preceding and following position of the target C. For recording, a list of twelve Hindko stops is prepared as shown in the table below:

Table 7: List of target stops in iCi sequence

\begin{tabular}{|l|c|c|c||}
\hline Stops & Voiceless unaspirated & Voiced unaspirated & Voiceless aspirated \\
\hline \hline Bilabial & $\mathrm{ipi}$ & $\mathrm{ibi}$ & $\mathrm{ip}^{\mathrm{h}_{\mathrm{i}}}$ \\
\hline Dental & $\mathrm{itji}$ & $\mathrm{idj}$ & $\mathrm{itn}_{n}^{\mathrm{h}_{\mathrm{i}}}$ \\
\hline Alveolar & $\mathrm{iti}$ & $\mathrm{idi}$ & $\mathrm{it}^{\mathrm{h}_{\mathrm{i}}}$ \\
\hline Velar & $\mathrm{iki}$ & $\mathrm{igi}$ & $\mathrm{igi}^{\mathrm{ki}}$ \\
\hline
\end{tabular}

\subsection{Procedure}

Each participant repeated the 12 stimuli 3 times for a total of 36 stimuli per participant. Totally, 360 tokens (12 stop consonants x 3 repetitions x 10 participants) were analyzed to determine acoustic cues. Before recording, a brief session of instruction regarding how and what to do was held. For familiarization, each participant rehearsed the target words. The list of target words was given and for each repetition the order was changed. The data were recorded using high fidelity microphone directly on PRAAT software. A statistical package for social sciences (SPSS) was used for statistical analysis where possible.

\section{Results and discussion}

The results are stated and discussed under the relevant headings.

\subsection{VOT}

The results of VOT measurements for Hindko stops are summarized in the following tables: 
Table 8: Mean VOT and standard deviation for Hindko bilabial stops

\begin{tabular}{|l|c|c|c||}
\hline Bilabials & No. of Tokens & Mean & Standard Deviation \\
\hline \hline $\mathrm{p}$ & 30 & 25 & 1.15 \\
\hline $\mathrm{p}^{\mathrm{h}}$ & 30 & 65 & 2.94 \\
\hline $\mathrm{b}$ & 30 & -125 & 3.03 \\
\hline
\end{tabular}

Table 9: Mean VOT and standard deviation for Hindko dental stops

\begin{tabular}{|l|c|c|c||}
\hline \hline Dental & No. of Tokens & Mean & Standard Deviation \\
\hline \hline $\mathrm{t}$ & 30 & 19 & 4.20 \\
\hline $\mathrm{t}^{\mathrm{h}}$ & 30 & 76 & 3.05 \\
\hline $\mathrm{d}$ & 30 & -112 & 2.00 \\
\hline
\end{tabular}

Table 10: Mean VOT and standard deviation for Hindko alveolar stops

\begin{tabular}{|l|c|c|c||}
\hline Alveolar & No. of Tokens & Mean & Standard Deviation \\
\hline \hline $\mathrm{t}$ & 30 & 27 & 1.15 \\
\hline $\mathrm{t}^{\mathrm{h}}$ & 30 & 77 & 1.82 \\
\hline $\mathrm{d}$ & 30 & -120 & 2.86 \\
\hline
\end{tabular}

Table 11: Mean VOT and standard deviation for Hindko velar stops

\begin{tabular}{|l|c|c|c||}
\hline Velar & No. of Tokens & Mean & Standard Deviation \\
\hline \hline $\mathrm{k}$ & 30 & 42 & 1.41 \\
\hline $\mathrm{k}^{\mathrm{h}}$ & 30 & 91 & 1.61 \\
\hline $\mathrm{g}$ & 30 & -149 & 2.21 \\
\hline
\end{tabular}

Table 12: Mean VOT values (ms)

\begin{tabular}{|l|c|c|c|}
\hline & voiced & unaspirated & aspirated \\
\hline \hline Bilabial & -125 & 25 & 65 \\
\hline Dental & -112 & 19 & 76 \\
\hline Alveolar & -120 & 27 & 77 \\
\hline Velar & -149 & 42 & 91 \\
\hline \hline
\end{tabular}


As mentioned above, Hindko has three way contrast series of stops namely voiced, voiceless unaspirated and voiceless aspirated. The voiced stops $/ \mathrm{b}, \mathrm{d}_{\mathrm{d}} \mathrm{d}, \mathrm{g} / \mathrm{have}$ negative VOT ranging from -112 (dental) to -149 (velar). The voiceless unaspirated plosives /p, t $\mathrm{t}, \mathrm{k} / \mathrm{have}$ positive VOT ranging from 19 (dental) to 42 (velar). The voiceless aspirated stops $/ \mathrm{p}^{\mathrm{h}}, \mathrm{t}^{\mathrm{h}}, \mathrm{t}^{\mathrm{h}}, \mathrm{k}^{\mathrm{h}} /$ have also positive VOT ranging from 65 (bilabial) to $91 \mathrm{~ms}$ (velar) which is fairly longer than voiceless unaspirated stops. Following figure 2 reflects a comparative sketch on the basis of average mean values which are -126.5 for voiced, 28.25 for voiceless unaspirated and 77.25 for voiceless aspirated stops:

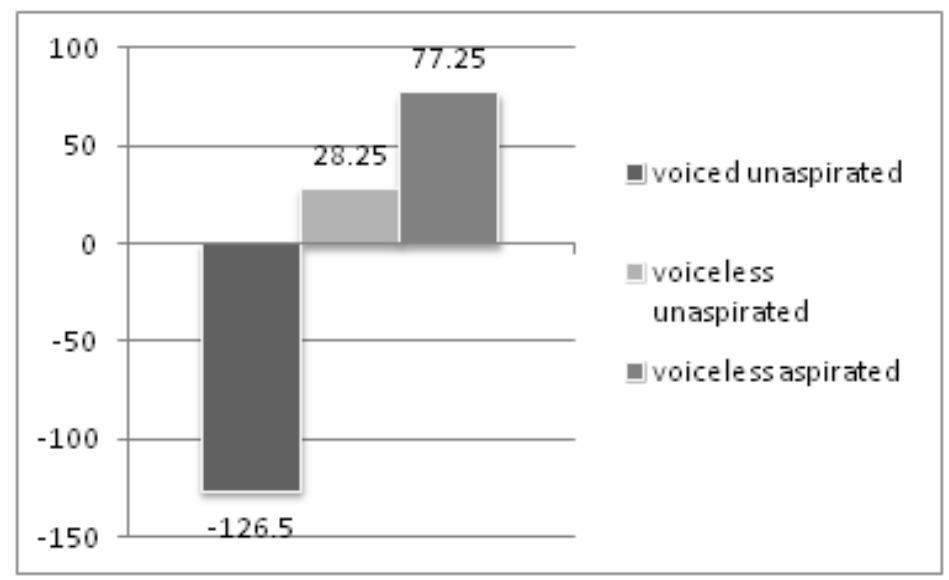

Figure 2: Average Mean VOT for voiced, voiceless unaspirated and voiceless aspirated stops in Hindko

Figure 2 clearly shows that the degree of VOT difference is evident. The hierarchy is as voiceless aspirated $>$ voiceless unaspirated $>$ voiced.

Statistically, a single factor ANOVA confirms that the P-value is smaller than 0.05 which implies that the difference is highly significant between the three voicing types. Thus, it can be concluded that Hindko demonstrates a pattern found in many other languages of the world: voiceless stops have short VOT, Voiceless aspirated have long VOT while voiced stops are produced with prevoicing.

As the average means values given above in the table 11 indicates that Hindko stops are distinguishable on the ground of the place of articulation. This difference is visible in the figure 3 : 


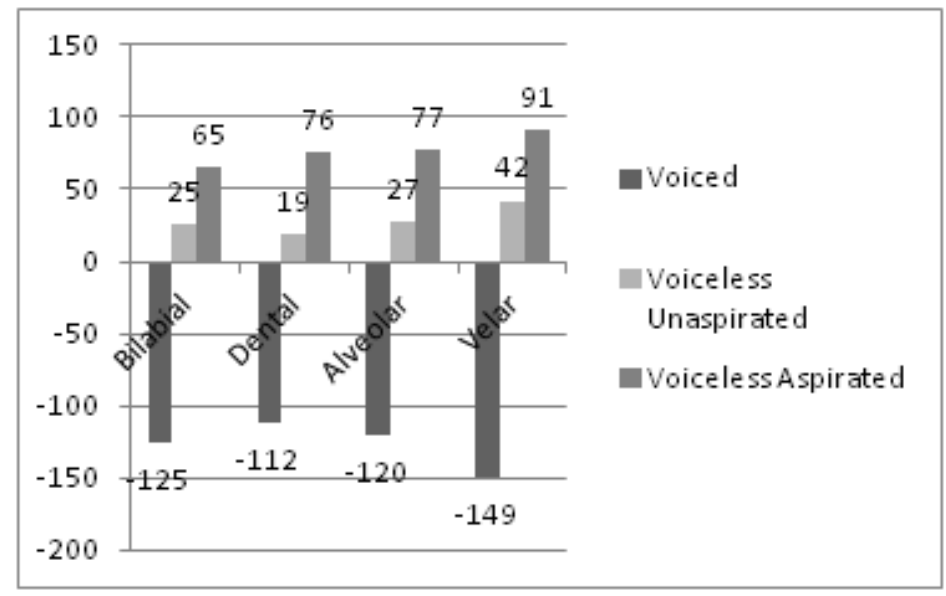

Figure 3: Mean VOT values (ms) for bilabial, dental, alveolar and velar stops of Hindko

Figure 3 is illustrious of the difference among stops produced from different places. The following table presents average mean VOT for different places of articulation.

Table 13: Average VOT by place of articulation

\begin{tabular}{|c|c|}
\hline Places of articulation & Average VOT (ms) \\
\hline \hline Bilabial & 45 \\
\hline Dental & 47.5 \\
\hline Alveolar & 52 \\
\hline Velar & 66.6 \\
\hline
\end{tabular}

To check the significance, one way ANOVA test was performed which shows that there is a highly significant difference between bilabial, dental, alveolar and velar as the P-value is smaller than 0.05. Moreover, the pairwise test between bilabial-dental, bilabial-alveolar, bilabial-velar, dental-alveolar, dental-velar and alveolar-velar is also found significant.

This study reveals that Hindko stops are consistent with Cho \& Ladefoged (1999) finding in a cross linguistic investigation that VOT increases with the backness of a plosive's place of articulation as the VOT in Hindko stops is increasing which means that the further back the place of articulation is the longer the VOT. However, this study does not supplements Hardcastle's (1973) finding that the faster the movement of the articulators, the shorter the VOT. The VOT hierarchy in terms of place of articulation is: Velar > alveolar > dental > bilabial. 
This study on VOT in terms of voicing and place of articulation of Hindko stops finds that:

- Velar stops have the longest VOT while bilabial have the shortest.

- The hierarchy by place of production of stops is Velar $>$ alveolar $>$ dental $>$ bilabial.

- Statistically, all the F-test results are significant as the P-value is smaller than .05 the level of significance. Even pairwise tests like bilabial-dental, bilabial-alveolar, bilabial-velar, dental-alveolar, etc. are also found significant.

- The study supports the cross linguistic finding the further back the closure, the longer the VOT (Fischer-Jorgensen, 1954; Peterson \& Lehiste, 1960) rather than Hardcastle's (1973) finding that the faster the movement of the articulators, the shorter the VOT.

\subsection{Closure duration}

This section discusses the closure duration of Hindko stops in terms of articulatory place and voicing quality. The following table exhibits the closure duration of Hindko stops by place of articulation:

Table 14: Closure duration by place of articulation (ms)

\begin{tabular}{|l|l|l|l|}
\hline & Voiced & $\begin{array}{l}\text { Voiceless } \\
\text { unaspirated }\end{array}$ & Voiceless aspirated \\
\hline Bilabial & 98 & 126 & 118 \\
\hline Dental & 95 & 116 & 110 \\
\hline Alveolar & 94 & 114 & 107 \\
\hline Velar & 90 & 105 & 102 \\
\hline
\end{tabular}

The figure 4 illustrates the difference that exists within groups by place of articulation. 


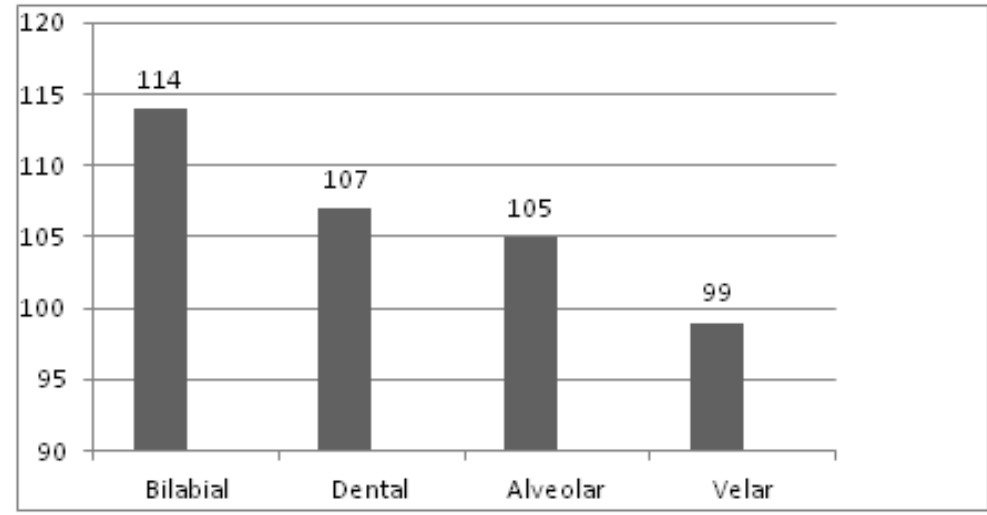

Figure 4: Closure duration by place of articulation

This figure shows that there is a clear difference within bilabial, dental, alveolar and velar. The closure duration is the maximum for the bilabial $(114 \mathrm{~ms})$ and minimum (99 ms) for the velar stops. These results supplement Maddieson's (1991) finding, i-e. the closure duration reduces with the backness of the tongue. Besides, this study also supports the results found in Anderson and Maddieson (1994) which claims that the shortest closure duration among coronal stops is of alveolar phonemes as shown in the figure 4 .

F-test demonstrates that the difference of closure in four places of articulation is significant as the P-value is smaller than 0.05 the level of significance. Pairwise differences are also significant.

The following figure shows the closure duration by voicing type:

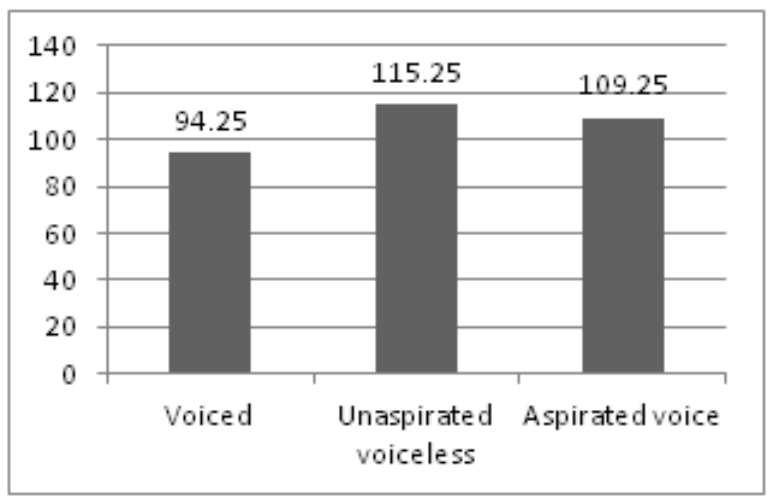

Figure 5: Closure duration by voicing type 
Figure 5 reflects the following hierarchy of the closure duration: Unaspirated voiceless > aspirated voiceless > voiced. One way ANOVA shows the differences are significant. Moreover, pairwise differences are also significant.

Winding up closure duration and VOT in Hindko, both are effective acoustic cues to distinguish plosives in terms of place and voicing. The relationship between Closure duration and VOT is a reverse one, i-e. the closure duration decreases as the VOT increases. Putting both together, the difference in overall stop duration is no longer significant as shown in the figure 6.

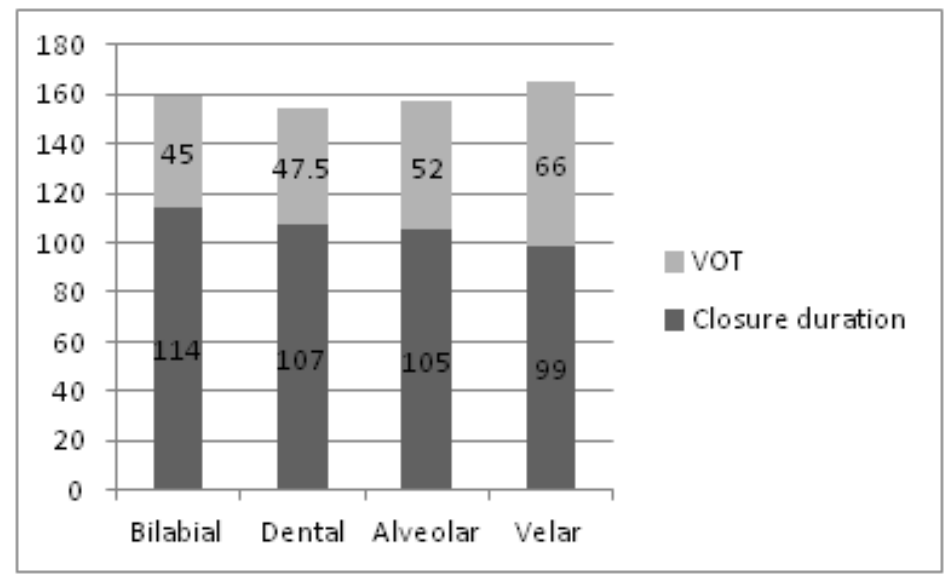

Figure 6: Stop duration (Closure duration + VOT)

The above discussion indicates that the study of Hindko stops supports the claim by Lehiste (1960) that characteristically VOT increases with the backness of a stop's place of articulation. This study is also supportive to the finding of Madieson (1997) that the stop closure duration for bilabial stops is, in general, longer than that of alveolar and velar, possibly due to different degree of air pressure in the cavity behind the construction.

\subsection{Burst as acoustic cue}

The following figures 7-10 present the burst, indicated in between vertical lines on the spectrogram, of voiceless stops in Hindko at four places of articulation: 


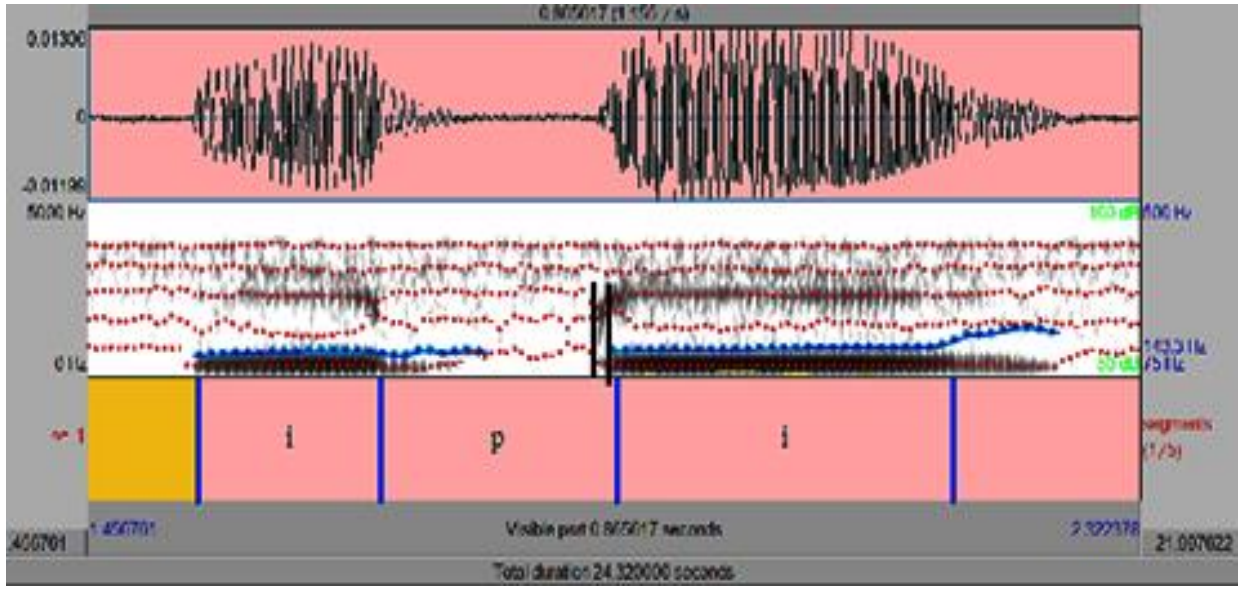

Figure 7: Burst of bilabial voiceless stop /p/

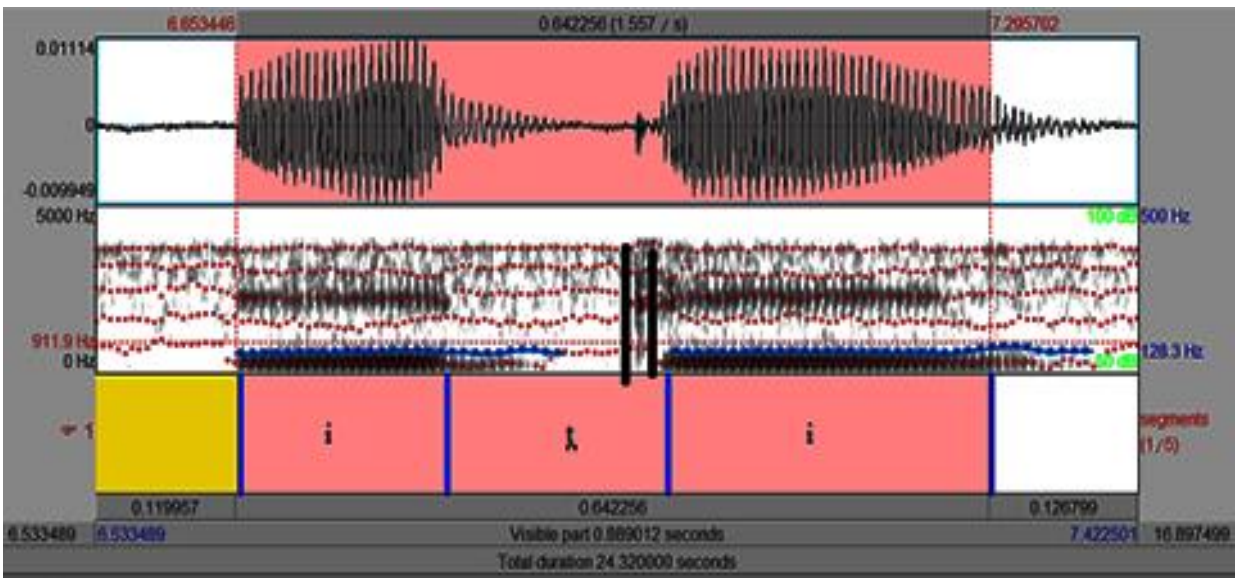

Figure 8: Burst of dental voiceless stop / $\mathrm{n} /$

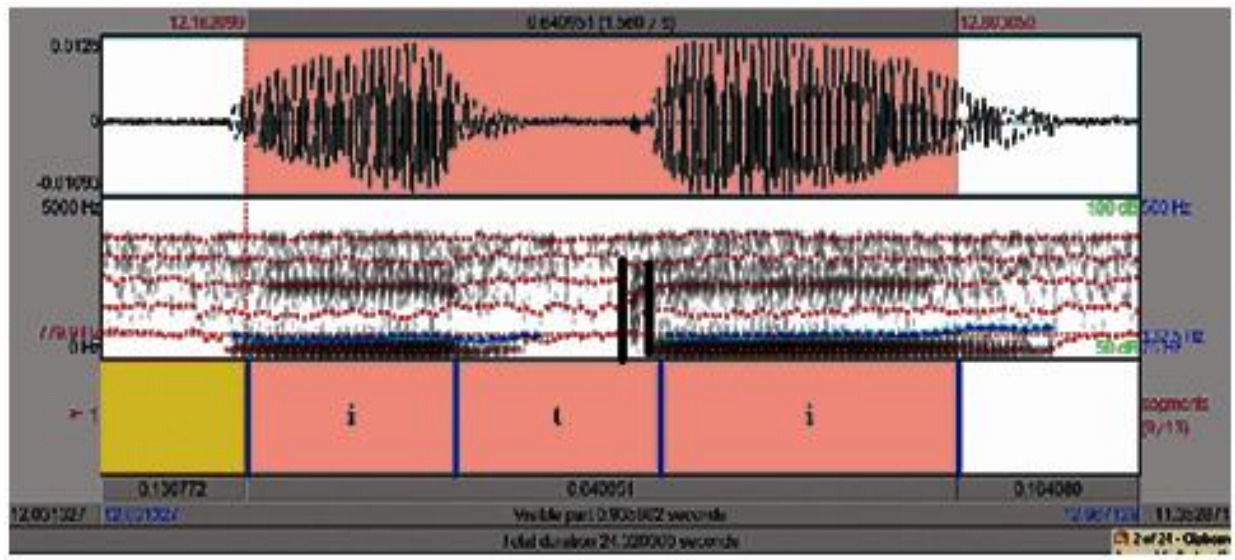

Figure 9: Burst of alveolar voiceless stop /t/ 


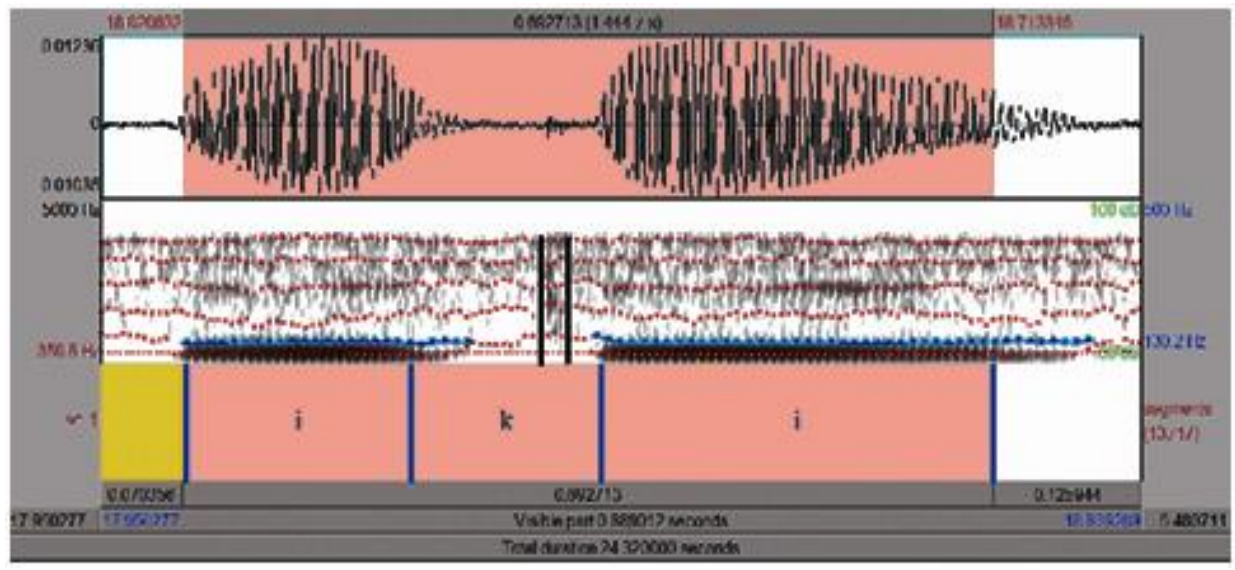

Figure 10: Burst of velar voiceless stop /k/

The spectrogram in the figure 7 clearly indicates that bilabial burst is falling as it fades away going upward. The bursts for dental and alveolar in the figures 8-9 are rising respectively. However, the difference is that burst for dental is strong while for alveolar a faint one. The velar as in the figure 10 has a compact burst in the midfrequency range. Hence, the burst is also an effective cue like VOT and closure duration to distinguish stops. This study of burst in Hindko stops supplements the findings of Stevens and Blumstein (1978) as stated above. The findings are stated below:

Table 15: Burst spectrum by place of articulation

\begin{tabular}{||l|l|}
\hline Place & Burst spectrum \\
\hline Bilabial & Falling \\
\hline Dental & Rising (strong) \\
\hline Alveolar & Rising \\
\hline Velar & Compact (mid-frequency) \\
\hline
\end{tabular}

\section{Findings}

This acostic study of Hindko oral stops finds that:

- Bilabial: VOT minimum, closure duration maximum and the burst weak and falling.

- Dental: VOT longer than bilabial, closure duration lesser than bilabials and the burst rising (strong). 
- Alveolar: VOT longer than dentals, closure duration shorter than dentals and the burst rising.

- Velar: VOT the longest, closure duration the shortest and the burst compact (mid-frequency).

\section{Conclusion}

The phonemic analysis identifies that Hindko has twelve oral stops articulated from four different places of articulation: bilabial $/ \mathrm{p}, \mathrm{b}, \mathrm{p}^{\mathrm{h}} /$, dental $/ \mathrm{t}, \mathrm{d}, \mathrm{t}_{\mathrm{h}}^{\mathrm{h}} /$, alveolar $/ \mathrm{t}, \mathrm{d}, \mathrm{t}^{\mathrm{h}} /$ and velar $/ \mathrm{k}, \mathrm{g}, \mathrm{k}^{\mathrm{h}} /$. It also reveals that the oral stops display a three way voicing contrast. This is voiced $/ \mathrm{b}, \mathrm{d}_{\mathrm{r}} \mathrm{d}, \mathrm{g} /$, voiceless unaspirated $/ \mathrm{p}, \mathrm{t} \mathrm{t}, \mathrm{k} /$ and voiceless aspirated $/ \mathrm{p}^{\mathrm{h}}, \mathrm{t}^{\mathrm{h}}, \mathrm{t}^{\mathrm{h}}, \mathrm{k}^{\mathrm{h}} /$. All the voiceless phonemes have aspiration contrast but voiced aspirated stops are non-existent in Hindko. This analysis also demonstrates that Hindko plosives exist word initial, medial and final positions except $/ \mathrm{p}^{\mathrm{h}} /$ that is restricted to only word initially and medially.

The acoustic analysis of these oral stops reveals that all the segments are distinguishable. In regard with this, VOT, closure duration and burst are effective and significant acoustic cues. VOT examination suggests that velar stops have the longest VOT while bilabial have the shortest. The hierarchy by place of production of stops is as velar > alveolar > dental > bilabial. Moreover, the statistical testing also confirms that there is a significant difference between these. Hence, the study on VOT of Hindko oral stops supplements the cross linguistic finding, i-e. it increases with the backness of the tongue. The closure duration is also a differentiating acoustic cue from place as well as voicing point of views. From the place of articulation perspective, there is a clear difference within bilabial, dental, alveolar and velar. The closure duration is the maximum for the bilabial $(114 \mathrm{~ms})$ and minimum $(99 \mathrm{~ms})$ for the velar stops. From voicing perspective the hierarchy of the closure duration is as unaspirated voiceless > aspirated voiceless > voiced. One way ANOVA shows the differences are significant. Even, pairwise differences are also significant. As far as the burst spectrum is concerned, it distinguishes Hindko oral stops as bilabials have a falling, dentals have a rising (strong), alveolars have a rising (weak) and velars have a compact (midfrequency) burst. Summing up, VOT, closure duration and burst are reliable and distinguishing intrinsic cues of oral stops in Hindko. 


\section{References}

Anderson, V. B. \& Maddieson, I. (1994). Acoustic characteristics of Tiwi coronal stops. Journal: UCLA Working Papers in Phonetics, 87, 131-162.

Boersma, P. (2012). Praat. Accessed from: http://.fon.hum.uva.nl.praat. (date last viewed $1 / 6 / 13)$.

Cho, T. \& Ladefoged, P. (1999). Variations and universals in VOT: Evidence from 18 languages. Journal of Phonetics, 27, 207-229.

Davenport, M., \& Hannahs, S. J. (2005). Introducing phonetics \& phonology. UK: Hodder Education.

Fischer-Forgensen, E. (1954). Acoustic analysis of stop consonants. Miscellanea Phonetics, 2, 42-59.

Halle, M., Hughes, C. \& Radley, J. P. (1957). Acoustic properties of stop consonants. Journal of Acoustical Society of America 29, 107-116.

Hardcastle, W. J. (1973). Some observations on the tense-lax distinction in initial stops in Korean. Journal of Phonetics, 1, 263-271.

Haroon-ur-Rashid \& Sohail, A. (2011). A brief introduction of Hindko language. Language in India, 11(11), 471-482.

Hussain, S. (2010). Phonetic correlates of Urdu lexical stress. Islambad: National Urdu Academy.

Keating, P. (1984). Phonetic and phonological representation of stop consonant voicing. Language, 60, 286-319.

Kent, R. D. \& Charles, R. (1996). Acoustic analysis of speech. San Diego: Singular Publishing Group.

Kiani, H. Z., Bukhari, N., Ahmed, J. \& Hameed, N. (2012). Acoustic analysis of Hindko stops. Kashmir Journal of Language Research, 15 (2), 135-150.

Klatt, D. H. (1975). Voice onset time, friction, and aspiration in word-initial consonants clusters. Journal of Speech and Hearing Research, 18, 686-706.

Ladefoged, P. (2001). A course in phonetics. USA: Harcourt College Publisher.

Lehiste, I. (1960). Segmental and syllabic quantity in Estonian American studies in Uralic Lingustics, 1. Bloomington: Indiana University.

Lisker, L. \& Abramson, A. S. (1964). A cross-language study of voicing in initial stops: Acoustical measurements. Word, 20, 384-422.

Loothers, M. \&Loothers, L. (2010). Pahari and Pothwari: A sociolinguistics survey Islamabad: Summer Institute of Linguistics.

Maddieson, I. (1984). Patterns of sounds. Cambridge: Cambridge University Press.

Maddieson, I. (1991). Testing the universality of phonological generalization with a phonetically specified segment database: Results and limitations. Phonetica, 48, 193-206.

Maddieson, I. (1997). Phonetic universals. In W. J. Hardcastle, \& J. Laver (Eds.) The Handbook of Phonetic Science (pp. 619-639). Oxford: Blackwell.

Peterson, G. E. \& Lehiste, I. (1960). Duration of syllable nuclei in English. Journal of the Acoustical Society of America, 3, 693-703. 
Pickett, J. M. (1999). The acoustics of speech communication fundamentals, speech perception theory, and technology. Boston: Allan and Bacon.

Stevens, K. N. \& Bloomstein, S. E. (1978). Invariants cues for place of articulation in stop consonants. Journal of the Acoustical Society of America, 64, 1358-1368.

Stevens, K. N., Keyser, S. J. \& Kawasaki, H. (1986). Toward a phonetic and phonological theory of redundant features. In S, J, Perkell \& D. H. Klatt (Eds.), Invariance and Variability in Speech Processes (pp. 426-499). Lawrence Erlbaum: NJ. 